\title{
Ujung Tradition in Nuclear Family: Linguistics Expressions and Cultural Meanings Inside It
}

\author{
Sigit Haryanto \\ Postgraduate Program \\ Universitas Sebelas Maret \\ Surakarta Indonesia \\ Wakit Abdullah \\ Postgraduate Program, \\ Universitas Sebelas Maret \\ Surakarta Indonesia \\ abdullahwakit@yahoo.com
}

sigitharyanto@student.uns.ac.id; sh288@ums.ac.id

\author{
Djatmika \\ Postgraduate Program \\ Universitas Sebelas Maret \\ Surakarta Indonesia \\ djatmika@staff.uns.ac.id \\ Dwi Purnanto \\ Postgraduate Program \\ Universitas Sebelas Maret \\ Surakarta Indonesia \\ dwi.purnanto@yahoo.com
}

\begin{abstract}
One of the spoken Javanese culture heritages that still carried out annually is ujung tradition. This tradition has close relation to lebaran day (ceremonial after fasting in a month). At that day or event, young, adult and old people celebrate happily. Ujung, really, is a part of a big tradition of bakdan. Bakdan may cover ambengan pudunan, ijab kobul zakat fitrah, idul fitri pray, ambengan idul fitri, ujung, and bakda kupat. Ujung tradition uses language as main media for transferring cultural meanings possessed by our predecessors. Understanding the cultural meanings is an important way to preserve the culture itself. There are two aims of this research; one is to find the linguistic forms used by the doers, and the second is to describe the cultural meanings inside the tradition. The data were collected by observation and interview. Then, the collected data were analyzed by using ethnography method proposed by Spradley. The data were taken at June 2017 in Cepogo, Boyolali, Central Java, Indonesia. The results founds are as follows: the first, concerning with the linguistic forms used by the doers (Person 1 and person 2), there are three languages that used in ujung tradition, those are, Javanese, Arabic, and Indonesian language. The dominant language is Javanese. Javanese language mostly consists of two, namely krama and ngoko. Krama is usually uttered by person 1 , and ngoko is uttered by person 2. The use of Arabic language commonly happens in the beginning of the procession. Indonesian language is used when the persons are not able to speak Javanese. The second, concerning with some cultural meanings inside the ujung tradition, Those meanings are advising and blessing, strengthening the neighborhood, cultural education, respect each other, charity media, mutual forgiveness, and silaturrahim. Based on the results, especially on cultural meanings, it is wisely suggested that the ujung tradition should be preserved and strengthened because the cultural meanings inside it are still $s$ uitableand needed in keeping the social life harmonization.
\end{abstract}

Keywords-linguistic forms; cultural meanings; ujung tradition; javanese culture

\section{INTRODUCTION}

Javanese people have many cultures or traditions. One of the traditions that still exist up to now is ujung. This tradition has a closed relation to lebaran (ceremony after doing fasting in a month) (Hakam, 2015). Lebaran in some places is called bakdan. Lebaran or bakdan consist of many activities, and one of the activities is ujung. Ujung or sometime called halal bi halal refers to the terms of forgiveness after fasting Ramadan (Aly, 2005). Ujung is also given a meaning a devotion while kissing the knee (prawiro Atmodjo s, 1996, p. 408). The practices of mutual forgiveness are usually done by the young people to older people and started from nuclear family then proceed to extended family. A mutual forgiveness uses Javanese language.

Ujung is really a complex activity. It has linguistic expression, nonlinguistic expression, and cultural meaning. If only discussing linguistic expression, it only knows the surface culture and if discussing the cultural meaning is the same as understanding the deep culture. Dealing with surface and deep culture, some experts said that understanding a tradition or culture is generally done by understanding linguistic expressions (words, phrases, clauses, sentences, and discourses) and non linguistic (symbols, signs, offerings, and events) (Fernandez, 2008; Abdullah, 2013, Hartini, 2014).

Linguistic expressions become the opening door of what is actually the essence of the tradition (Abdullah, 2016). To gain a complete understanding of a tradition, the path that can be traversed is by understanding both, the language used and uncovering the meaning in it. The relationship of both, language and culture, in linguistics is embodied in the field of ethnolinguistic study. Ethnolinguistics is interdisciplinary field (Foley, 2001; Duranti, 2003). It is a combination of anthropology and linguistics, specifically between language and culture, so it may be mentioned that ethnolinguistics is a study of the correlation between language and culture.

Linguistic expressions used in ujung is commonly krama and ngoko code. Krama is uttered by the young people, and older people use ngoko. However, in specific case, older 
people use krama to young people. This is caused by social strata or social status. The linguistic expressions and the figure of ujung are provided below.

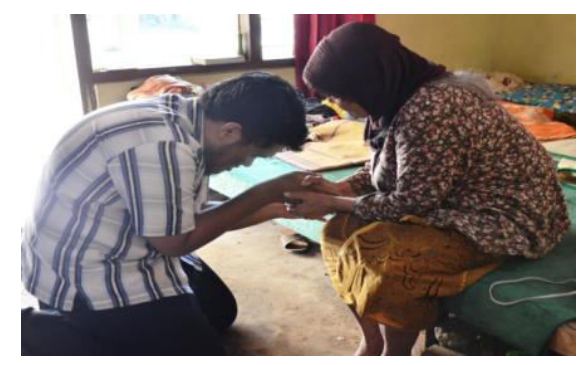

Fig.1. Linguistic expression and the scene

Young people: Mbah ngaturaken sugeng riyadin, sedaya kalepatan nyuwun ngapunten.

'Nenek, mengucapkan selamat hari raya, semua kesalahanku mohon dimaafkan'

'Grandma, happy lebaran day, all my mistakes let be forgiven'

Old people: $\quad$ Nenek: Ya le, sepira luputku aku njaluk ngapura, dosaku lan dosamu muga-muga lebur ana ing dina bakda iki, dongaku wae marang kowe muga-muga sekolahmu lancar, lan sing bekti marang wong tuwa'

'Ya mas seberapa kesalahan saya, saya minta maaf, dosa saya dan dosa kamu semoga hapus di hari raya ini, doa saya pada mu semoga sekolahmu lancar dan yang berbakti kepada kedua orang tuamu'

'yes son, all my mistakes I ask excuse, my sin and your sin may be wiped out in this day, my pray to you may your study get success and always devote to your parent.'

From the short dialogue above, it is understood that there are two codes of Javanese language used, young people use krama, and old people use ngoko. The young respects to the old by uttering krama, and the old uses ngoko to show her status. Speech level in Javanese may have three levels: krama, madya, dan ngoko (Kridalaksana, 2001), however in general understanding the level is divided into two: krama and ngoko (Suryadi, 2014). The easy way to differentiate krama and ngoko is seen from the vocabulary use, example: ngoko 'sepiro luputku', krama: 'sedaya kalepatan'. Both refer to the same meaning that is all my mistakes.

In the reality, linguistic expressions used in ujung are not only Javanese language, people sometime blend or mix with the Arabic language. For instance: taqabalallahu minna wa minkum, minal aizin wal faizin, mas sedeya kalepatan kula nuwun pangapunten. From the examples above, it is interesting to be investigated deeply concerning with what the linguistic expressions used by the doers of ujung tradition. Besides, meanings behind the utterances used by the people in this tradition are also interesting to be explored. At a glance, there are some meanings, such as respect, Multilanguage, and etc. Two things, linguistic expressions and the meanings inside the use of linguistic expression become the focus of this article.

\section{METHOD}

This qualitative research used observation participation and interview for collecting the data. The data were utterances spoken by the people who lived in Cepogo Boyolali. The fifty data that taken on Juni 2017were analyzed by using componential analysis proposed by Spradley, James P. (2007) and Santosa (2017).Then the results of data analysis were presented descriptively.

\section{RESULT AND DISCUSSION}

Based on the data analysis, the writer found three languages used in ujung tradition, those are Javanese, Arabic, and Indonesian language. Javanese language is dominant. The second is Arabic, and the third is Indonesian. The Arabic was used or mixed with Javanese and usually the Arabic uttered in the beginning. Ujung with Indonesian language was done by the people who use Indonesian language in daily communication and are not be able to speak Javanese language. $\mathrm{O} 2$ as receiver usually uses Indonesian language in responding. The representation of linguistic expressions presented in table 1 .

TABLE I. THREE LANGUAGES USED IN UJUNG TRADITION

\begin{tabular}{|c|c|c|c|}
\hline No & Javanese & Arabic & Indonesian \\
\hline 1 & $\begin{array}{l}\text { Ya mas, pada- } \\
\text { pada, dosamu } \\
\text { lan dosaku } \\
\text { muga-muga } \\
\text { lebur ana bakda } \\
\text { iki' } \\
\text { Ok boy, equals, } \\
\text { your sin and my } \\
\text { sin may be wiped } \\
\text { out in this } \\
\text { lebaran day }\end{array}$ & $\begin{array}{l}\text { 'taqabalallahu minna } \\
\text { wa minkum, minal } \\
\text { aizin wal faizin,' mas } \\
\text { sedya kalepatan kula } \\
\text { nyuwun panga } \\
\text { punten } \\
\text { May Allah accept it } \\
\text { from us and you, } \\
\text { brother all my } \\
\text { mistakes may be } \\
\text { forgiven. } \\
\text { A'ūdzu billāhi } \\
\text { minas-syaitānir- } \\
\text { rajīmi, bismillah } \\
\text { hirrahman nirrahim, } \\
\text { Mbah ngaturaken } \\
\text { sugeng riyadi, sedaya } \\
\text { kalepatan } \\
\text { nyuwun kula } \\
\text { pangapunten' } \\
\text { I seek protection } \\
\text { from Allah from the } \\
\text { cursed devil" } \\
\text { In the name of God, } \\
\text { the Gracious, the } \\
\text { Merciful. } \\
\text { Grandma/fa happy } \\
\text { lebaran day, forgive } \\
\text { all my mistakes }\end{array}$ & 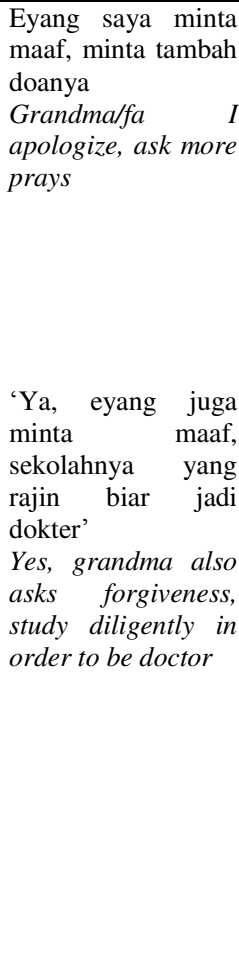 \\
\hline
\end{tabular}

As we have known that Javanese language has speech level, and commonly it is divided into two, namely krama and ngoko. The first refers to high level, and the second refers to low level. The use of krama and ngoko depends on some factors, such as the position in nuclear family, social status, and new or old person. 
In Javanese nuclear family, the older position/rank will get krama from the younger rank (Geertz, Hildred,1961; Sutardjo, 2008). It is proved when the researcher observed the activities happened when they were doing ujung. Father got krama from mother, then father responded with ngoko. After that it is continued by their sons. The oldest son held the father's hand and asked forgiveness (see figure 1), then went on to mother. The oldest son used krama to both, and both responded in ngoko. The next is the younger son did ujung to parents, then to oldest son. He/she used krama, then her/his parent responded in ngoko. The boys/girls of the oldest son or the younger son used krama to their grandparent, their father and mother. And the boys/girls got ngoko response from them. The traffic of the use krama and ngoko in nuclear family can be seen in the chart 1 .

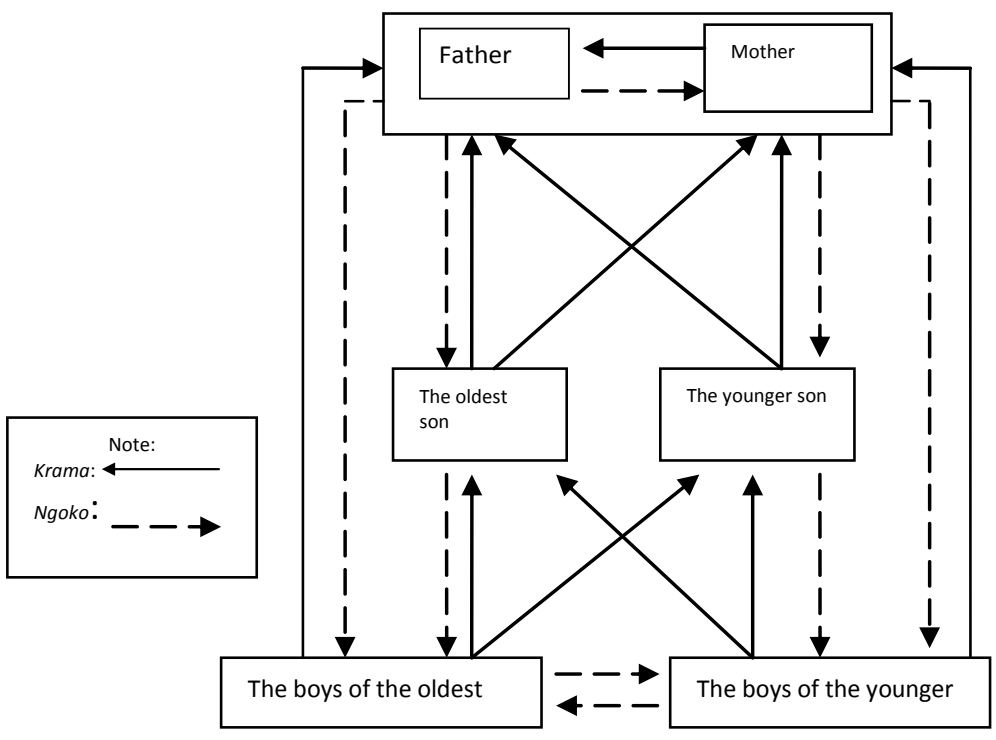

Chart 1 . The use of Javanese code (krama - ngoko) in nuclear family

The cultural meanings inside the use krama - ngoko are as follows: 1. Mother shows respect to father by using krama. Their sons and their grandchildren respect their parent and grandparent also uses krama. Father used ngoko to mother and their sons and their grandchildren. The meaning of using ngoko is to show higher position and intimacy. Other meaning of ujung is to make the relationship between them tightly (sillaturahim).

And if seen the content of linguistic expressions, the meanings of ujung may be as mutual forgiveness, advices and prays. Mutual forgiveness is sedaya kalepatan kula nyuwun pangapunten, 'forgive all my mistakes'; Eyang saya minta maaf, 'Grandma/fa I apologize'. Advices are reflected in the followings: sekolahnya yang rajin biar jadi dokter, 'study diligently in order to be doctor'; sing bekti marang wong tuwa 'devote to your parent'. Prays are as follows: dongaku wae marang kowe muga-muga sekolahmu lancar, 'my pray to you may your study get success'; tak suwunke marang Gusti, muga-muga apa sing dadi penjalukmu tansah dikabulake, 'I ask to the God may what you hopes are granted'.

\section{CONCLUSION}

Ujung as a part of bakdan is generally expressed in Javanese language. Two codes are used in this activity, namely krama and ngoko. Krama is used by the younger position/ rank in family, such as mother, their son, and their grandchildren. Ngoko is used by the parent and older position/rank in family, such as father, mother, and older brother.

The cultural meanings inside the ujung tradition may be seen from the use of the expressions and the events as long as the ujung tradition. From the content of the expression, ujung has meanings as a medium of mutual forgiveness, advice and pray. And if seen from events, the meaning of ujung is to tight the family relationship (sillaturahim).

Based on the results, especially on cultural meanings, it is wisely suggested that the ujung tradition should be preserved and strengthened because the cultural meanings inside it are still suitable and needed in keeping the social life harmonization.

\section{References}

Aly, A. (2005). Tradisi lebaran dan praktik hidup multikultural. Kalimatun Sawa', 03(01).

https://publikasiilmiah.ums.ac.id/bitstream/handle/1161 7/2164/KS\%203\%20-\%201.pdf; sequence $=1$

Abdullah, W. (2013). Kearifan lokal dalam bahasa dan budaya Jawa masyarakat nelayan di Pesisir Selatan Kebumen (sebuah kajian etnolinguiatik) (Disertasi). Surakarta: Universitas Sebelas Maret.

Abdullah, Wakit. (2016). Javanese language and culture in the expression kebo bule in Surakarta: an ethnolinguistic study. Komunitas, International Journal of Indonesian Society and Culture, 8(2). DOI: http://dx.doi.ord/10.15294/komunitas.v8i2.7195.

Duranti, Alessandro. (2003). Linguistic anthropology. Cambridge: Cambridge University Press.

Djojosuroto, Kinayati. (2013). Ikon tradisi ba'do katupat sebagai refleksi kebudayaan masyarakat Jaton di Sulawesi Utara, el Harakah, 15(2). Retrieved from http://ejournal.uinmalang.ac.id/index.php/infopub/article/view/2767

Fernandez, Inyo Yos. (2008). Kategori dan ekspresi linguistik dalam bahasa Jawa sebagai cermin kearifan lokal penuturnya: kajian etnolinguistik pada masyarakat petani dan nelayan. Jurnal Kajian Linguistik dan Sastra, 20(2).

Foley, William A. (2001). Anthropological linguistics. Oxford: Blackwell.

Geertz, Hildred. (1961). The javanese family: a study of kinship and socialization. The Free Press of Glencoe, Inc.: America.

Ghufron, Fathorrahman. (2016). Modal sosial halal bihalal. 
Retrieved from http://digilib.uin-suka.ac.id/23746

Hakam, Saiful. (2015). Halal bi halal, a festival of idul fitri and its relation with the history of islamization in Java. Episteme, Jurnal Pengembangan Ilmu Keislaman, 10(2), 386-403. Retrieved from http://ejournal.iaintulungagung.ac.id/index.php/epis/about/contact

Hartini H.S., M. V. Sri. (2014). Kategori dan ekspresi linguistik sebagai cermin kearifan lokal etnik jawa di kabupaten kebumen kajian etnolinguistik komunitas petani (Disertasi). Surakarta: Universitas Sebelas Maret.

Koentjaraningrat. (1984). Kebudayaan Jawa. Jakarta: Balai Pustaka.

Kramsch, Claire. (1998). Language and culture. Oxford: Oxford University Press.

Kridalaksana, Harimurti. (2001). Wiwara pengantar bahasa dan kebudayaan Jawa. Jakarta: PT Gramedia Pustaka Utama.

Magnis-Suseno, Franz. (2001). Etika Jawa. Jakarta: Gramedia Pustaka Utama.

Mulder, Neils. (1984). Kepribadian Jawa dan pembangunan nasional. Yogyakarta: Gadjah Mada University.

Poedjosoedarmo, Soepomo., Kundjana Th., Gloria Soepomo, Alif, dan Sukarso. (1979). Tingkat tutur bahasa Jawa. Jakarta: Pusat Pembinaan dan Pengembangan Bahasa.

Rahardi, Kunjana. (2009). Bahasa prevoir budaya. Yogyakarta: Pinus Book Publisher.

Santosa, Riyadi. (2017). Metode penelitian kualitatif kebahasaan. Surakarta: Universitas Sebelas Maret Press.

Sairin, Sjafri. (1982). Javanese trah: kin-based social organization. Yogyakarta: Gadjah Mada University Press.

Spradley, James P. (2007). Metode etnografi. Yogyakarta: Tiara budaya Yogya.

Suseno, Franz Magnis. (1999). Etika Jawa. Jakarta: PT Gramedia.

Sutardjo, Imam. (2008). Kajian budaya Jawa. Surakarta: Jurusan Sastra Daerah Fakultas Sastra dan Seni Rupa Universitas Sebelas Maret Surakarta.

Supandi. (2014) Makna dan pengaruh tradisi syawalan bagi masyarakat multi-agama di komplek Mandala Asri Yogyakarta (Skripsi). Jurusan perbandingan agama fakultas ushuluddin dan pemikiran Islam Universitas Islam Negeri Sunan Kalijaga Yogyakarta. Retrieved from http://digilib.uin-suka.ac.id/11774

Soelarto. (1993). Garebeg di Kesultanan Yogyakarta. Yogyakarta: Kanisius.

Suryadi. (2014). Penggunaan tingkat tutur bahasa Jawa ngoko dan krama pada ranah keluarga dan masyarakat di Kota Semarang dan Kota Pekalongan (Disertasi). Surakarta: Universitas Sebelas Maret. 